\title{
Current use of intraosseous infusion in Danish emergency departments
}

\author{
Rune Molin ${ }^{1 *}$, Peter Hallas ${ }^{2}$, Mikkel Brabrand ${ }^{3}$, Thomas Andersen Schmidt ${ }^{1}$ \\ From Danish Society for Emergency Medicine: Research Symposium 2010 \\ Roskilde, Denmark. 20-21 May 2010
}

\section{Background}

We have evaluated the current use of intraosseous infusion (IOI) in Danish emergency departments. The use of IOI is recommended when intravenous access cannot be readily established in both paediatric and adult resuscitation.

\section{Methods}

Links to an online questionnaire were e-mailed to the Chief of Staff of the twenty emergency departments currently established in Denmark; non-responders were contacted by telephone. The questionnaire focused on the use of IOI in the emergency department including training, equipment, and attitudes.

\section{Results}

Overall response rate was $95 \%(\mathrm{n}=19)$. Of the responding Danish emergency departments $74 \%(n=14)$ have intraosseous devices. Despite this 33\% $(n=6)$ of the departments did not use intraosseous devices at all and in $68 \%(\mathrm{n}=13)$ it was used infrequently.

In $47 \%(\mathrm{n}=9)$ of the departments there had never been any training sessions in the use of intraosseous devices, and $42 \%(\mathrm{n}=8)$ did not have standard operating procedures on IOI. The indication for IOI use was often not clearly defined and only $11 \%(n=2)$ consistently used IOI on relevant indication. This was a surprise since $95 \%(n=18)$ of responders were aware that IOI can be used in both paediatric and adult resuscitation.

\section{Conclusion}

IOI is seldom performed in Danish emergency departments and few departments have established training in

\footnotetext{
* Correspondence: molin@dadlnet.dk

'Department of Emergency Medicine, Holbæk Sygehus, Holbæk, Denmark Full list of author information is available at the end of the article
}

the procedure. We recommend teaching IOI technique to medical staff in Danish emergency departments.

\section{Author details}

'Department of Emergency Medicine, Holbæk Sygehus, Holbæk, Denmark. 2Department of Anaesthesiology, JMC, Rigshospitalet, Copenhagen, Denmark. ${ }^{3}$ Department of Medicine, Sydvestjysk Sygehus, Esbjerg, Demark.

Published: 17 September 2010

\section{doi:10.1186/1757-7241-18-S1-P8}

Cite this article as: Molin et al:: Current use of intraosseous infusion in Danish emergency departments. Scandinavian Journal of Trauma

Resuscitation and Emergency Medicine 2010 18(Suppl 1):P8.
Submit your next manuscript to BioMed Central and take full advantage of:

- Convenient online submission

- Thorough peer review

- No space constraints or color figure charges

- Immediate publication on acceptance

- Inclusion in PubMed, CAS, Scopus and Google Scholar

- Research which is freely available for redistribution

Submit your manuscript at www.biomedcentral.com/submit
C Biomed Central 